\title{
The history of the interpretation of Matthew: Lessons learned
}

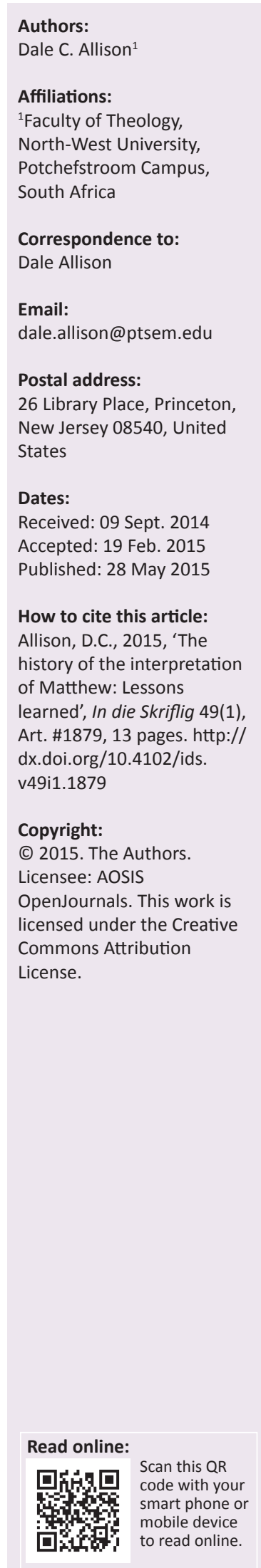

Scholars pay attention to the history of interpretation of biblical texts and of their reception for multiple good reasons. This essay urges that, in addition to the reasons typically offered, careful Wirkungsgeschichte can sometimes bring to light credible exegetical and historical proposals that were once in the commentary tradition but dropped out for no apparent or good reason. Such proposals need to be restored to the tradition. I shall offer several illustrations, including the old association of Matthew 5:21-26 with the sacrifice of Cain and Abel and the ancient linking of Matthew 9:20-21 and 14:36 with the prophecy of Malachi 4:2 ('The Son of Righteousness will arise with healing in his wings'). The article also, however, draws attention to some of the limitations of Wirkungsgeschichte for historical exegesis.

Die interpretasiegeskiedenis van Matteus: Lesse geleer. Navorsers skenk aan die interpretasiegeskiedenis van bybelse tekste en die ontvangs van die verskillende tekste om verskeie redes aandag. Hierdie artikel toon aan dat, behalwe vir redes wat normaalweg aangebied word, 'n noukeurige 'Wirkungsgeschichte' soms geloofwaardige eksegetiese en historiese voorstelle na vore kan bring wat tevore wel tot die kommentaretradisie behoort het, maar gaandeweg in onbruik verval het. Sodanige voorstelle behoort weer tot die tradisie toegevoeg te word. Ter stawing hiervan kan verskeie voorbeelde genoem word soos die bekende assosiasie van Matteus 5:21-26 met die offer van Kain en Abel en die oeroue koppeling van Matteus 9:20-21 en 14:36 met die profesie van Maleagi 4:2 ('Die son van geregtigheid sal verrys met genesing in sy vleuels'). Hierdie artikel vestig egter ook die aandag op sekere beperkings van die 'Wirkungsgeschichte' vir die historiese eksegese.

\section{Introduction}

The history of interpretation, by which is meant the study of the interpretive history found in formal exegetical and theological works, and its relative, reception history, by which is meant the study of the construction and application of texts beyond formal theological and exegetical work, are quite the fashion these days. Examples of these are a journal entitled Reception history and another named Biblical reception; De Gruyter's new monograph series, Studies of the Bible and its reception; InterVarsity's highly successful Ancient Christian commentary on Scripture and its new companion series, Ancient Christian texts (the latter features such volumes as Origen on Numbers and Ambrosiaster on Romans and 1 and 2 Corinthians); we also have the rich history of interpretation sections in many of the volumes in the Evangelisch-Katholischer Kommentar zum Neuen Testament, including those translated into English, such as Ulrich Luz's $(2001 ; 2005 ; 2007)$ magnificent commentary on Matthew; there are further The Oxford handbook of the reception history of the Bible (Lieb, Mason \& Roberts 2011) and the Wiley-Blackwell Bible Commentary series with titles such as Lamentations through the centuries (Joyce 2013), Galatians through the centuries (Riches 2008), The pastoral epistles through the centuries, (Twomey 2009) and James through the centuries (Gowler 2014); and then there is De Gruyter's massive Encyclopedia of the Bible and its receptionnine volumes have appeared so far (Klauck et al. 2009-2014) and 21 more are projected.

Why the history of interpretation and reception history are so popular today is an interesting question. Part of the truth may be that, on some level, we fear or suspect that old-fashioned historical-criticism is nearing exhaustion, and so we must find something else to do. Another motivating factor is surely the postmodern proclivity to recognise that different historical and different personal contexts generate different readings of texts, and that texts accordingly have multiple meanings. Many of us are no longer hypnotised by the quest for some recommended original and so authoritative sense, whether of an author or of an author's first audience. We are keenly aware of the plasticity of texts, and how easily and thoroughly they succumb to interpretive agendas, conscious and unconscious. 
A technological factor is also at work here. Whilst there is no denying the current proliferation of books and articles that highlight the history of interpretation and reception history, there is also no denying the proliferation of books and articles on just about every other subject under the sun, within biblical studies as well as without. There is more of everything. Of this the explanation is not ideology but technology the means of production. We can produce more than in the past and are doing so. On top of this, there are far more New Testament scholars today than in the past as well as many more publications for what those scholars produce today than in the past; and in a publish or perish academy, it does not surprise that just about every subject is, in comparison with the past, thriving.

Whatever the reasons for the current interest in what the Germans call Wirkungsgeschichte, I would like to stress, before turning to Matthew, that the history of interpretation has been around, in one form or another, for a very long time. We are not doing something brand new, when we focus on what has been happening with a text in times gone by. We are rather continuing, expanding, and modifying an activity that has long been practiced. To be sure, I do not wish to deny the obvious, which is that the present is in many ways different from the past. Nonetheless, the history of interpretation has its own lengthy pedigree (cf. especially Klancher 2013:3-26).

Before the editors of De Gruyter's Encyclopedia of the Bible and its reception began to envisage their project, and before Luz started writing his commentary on Matthew, we had MohrSiebeck's series, Beiträge zur Geschichte der Biblischen Exegese. Its volumes started appearing in the 1950s, long before most New Testament scholars had heard of Wirkungsgeschichte (e.g. Künzi 1977; Prigent 1959; Schendel 1971). And three decades before Beiträge zur Geschichte der Biblischen Exegese, we had the wonderful, although unfortunately not well known, six volume contribution of Harold Smith (1925-1929) on patristic exegesis of the gospels. Beyond that, anyone who has spent time in the older commentaries knows that they were sometimes interested in earlier interpretation. The magisterial International critical commentary on James by James Hardy Ropes (1916:86-115) has a long and superb section on the use and interpretation of James throughout history.

Moving back to the 19th century, the exegesis in the commentary on the Sermon on the Mount of August Tholuck's (1860) is repeatedly oriented to the history of interpretation, and the multiple New Testament commentaries of H.A.W. Meyer (e.g. 1885) are full of references not only to German writers from his own time and immediately before, but also to Chrysostom, Theodoret, Bede, Oecumenius, Theophylact, Luther, Calvin, Erasmus, Beza, Bellarmine, Estius, Grotius, and Bengel. And this was nothing new. The commentaries of such influential Roman Catholic exegetes as John Maldonatus (1533-1583) and Cornelius Lapide (1567-1637) are overflowing with citations of patristic writers and medieval schoolmen (see e.g. De Maldonatus 1888; Lapide 2008).
One might of course expect this given the authority of tradition for their ecclesiastical tradition. Earlier Protestants, however, also minded the past to support and illuminate their own exegetical aims. The Puritan Thomas Manton (1620-1677), in his great commentary on James (1653), cites with profit texts from Tertullian, Eusebius, Jerome, Ambrose, Augustine, Chrysostom, Basil the Great, Gregory Nazianzen, Epiphanius, Ambrosiaster, Socrates Scholasticus, Bernard of Clairvaux, Ludolph of Saxony, Erasmus, Luther, and Beza. Even more noteworthy is the fascinating work of the French Huguenot polemicist Jean Daillé (1675). Unlike Manton, this work is purely polemical. It does, however, show a Protestant's vast knowledge of the history of interpretation.

I could of course keep moving back further in time until I arrived at the obvious, which is that, ultimately, all this attention to the history of exegesis had its birth in the traditional catenas, in the pre-Reformation commentaries that collected the opinions of predecessors, commentaries such as Aquinas' Catena Aurea on the gospels (2009). I have said enough, however, to establish that our present work is not unprecedented but rather the current phrase of a very long history.

The fact matters because it is all too easy to overvalue the present moment, to take all the credit for ourselves, to imagine that we perceive what everyone before us failed to see. Privileging recent work to the neglect of earlier work is, in my judgement, an unfortunate habit. Much that we think of as new, including the history of interpretation, is really old.

All interpreters, moreover, including modern historical critics, belong to a centuries-long, unfinished history of effects. We do not somehow stand outside of that history, and we are no more its end than we are its beginning. Further, we should not presume that our own agendas and perspectives - which will soon enough give way to different agendas and perspectives - are in every way superior to all that has come before us.

Important as these points are, however, I wish in this article to focus on something else. It is my conviction that the history of interpretation is important not only because it bestows upon us some humility and perspective by putting us in a large historical context, but because it can profoundly inform our own exegetical and historical judgements. The rest of this article is an attempt to establish and illustrate this claim from my own study of Matthew. What I wish to do, is reflect on the decades during which I have worked on and written about this Gospel and share some ways that the history of interpretation has served me to numerous good ends.

\section{Exegetical amnesia}

My first proposition is that careful attention to older writings sometimes allows one to recover exegetical suggestions and profitable lines of inquiry that, from an historicalcritical point of view, should never have dropped out of the 
commentary tradition but have done so. I offer in evidence four illustrations.

My first example of this phenomenon has to do with Matthew 5:21-26, where Jesus says:

If then you are offering your gift upon the altar and there remember that your brother has something against you, leave your gift there before the altar and go. First be reconciled to your brother, and then come and offer your gift.

I remember distinctly, when I was first working my way through the Sermon on the Mount, that I was at the same time going through the old volumes in the Ante-Nicene Fathers series, looking for whatever might illumine Matthew. Volume 5 had Cyprian in it, and I ran across two passages that grabbed my attention. The first was in Cyprian's treatise on The unity of the Catholic Church:

And so, if a person comes to the sacrifice with strife in his heart, he [Jesus] calls him back from the altar and bids him to be reconciled to his brother first, and then in peace of soul to return and to make his offering to God. For the very gifts of Cain did not win God's regard. Such a person could not have God at peace with him when he was torn with jealousy towards his brother and was at war with him. What sort of peace then do the enemies of the brethren promise themselves? What sort of sacrifice do they think they offer in competition with the priests? (sec. 13)

The second passage was in Cyprian's work on The Lord's Prayer:

God does not receive the sacrifice of a person who is in disagreement, but commands him to go back from the altar and first be reconciled to his brother, so that God also may be appeased by the prayers of a peacemaker. Our peace and brotherly agreement is the greater sacrifice to God ... For even in the sacrifices which Abel and Cain first offered, God looked not at their gifts, but at their hearts, so that he was acceptable in his gift who was acceptable in his heart. Abel, peaceable and righteous in sacrificing in innocence to God, taught others also, when they bring their gift to the altar, thus to come with the fear of God, with a simple heart, with the law of righteousness, with the peace of concord ... The quarrelsome and disunited and he who has not peace with his brothers. (23-24)

I had never before linked Matthew 5:21-24 with Cain and Abel and Genesis 4:1-16. But as I thought about the possibility, it came to appeal to me more and more. The two texts share several thematic and verbal links. If Matthew 5:21-24 opens by raising the subject of murder, Genesis 4 recounts the Bible's first murder. If Matthew 5:21-24 focuses on anger, Genesis 4:5 says that 'Cain was exceedingly angry' at Abel or on his account. If Matthew 5:21-24 addresses the relationship between brothers - the word occurs four times the same is true of Genesis 4:1-16. If, moreover, the situation in Matthew 5:23-24 is that of an individual offering a sacrificial gift on an altar, in Genesis the offering of sacrificial gifts is the proximate cause for Cain murdering his brother. In short, Matthew 5:21-24 concerns the affiliation of murder and anger, and it depicts a circumstance in which someone, whilst offering a gift on an altar, is upset with his brother all of which is strongly reminiscent of the story in Genesis, where Cain offers his gift, becomes angry, and attempts no reconciliation with his brother, whereupon murder ensues.

This intertextual reading was further attractive because the story of Cain murdering Abel has never been obscure. It rather belongs to Israel's foundational, primeval history, and ancient Jews and Christians must have known the stories in that portion of Scripture as well as any part of the Bible. So this is the sort of text readers might readily have called to mind with just a little prompting. Matthew 23:34-36 refers to 'the blood of Abel the just' without elaboration or explanation. Clearly the evangelist assumes an audience familiar with the story in Genesis, an audience that can easily call it to mind.

I began to think, then, that the image in Matthew is not of someone in the Jerusalem temple offering a gift at the altar and calling a halt to the official proceedings, as the modern commentators all assume even as they concede that such a circumstance would be peculiar. ${ }^{1}$ The image is instead of Cain, acting as priest for himself and offering his own sacrifice with his sibling nearby. It is true that Genesis 4 does not refer to the altars of Cain and Abel; but readers, knowing that there can have been no sacrifice without some sort of altar, have typically envisaged the brothers acting like Noah, Abraham, and Jacob, who are said to have built altars for their sacrifices (Gn 8:20; 12:7-8; 13:18; 22:9; 35:1-7). Certainly this is the lesson from art history: artists have traditionally supplied an altar or altars for Cain and Abel when depicting their sacrificial acts. (The most common artistic type has Cain and Abel on either side of the same altar.) So has Jewish haggadah. Targum Pseudo-Johathan on Genesis 8:20 reads:

Then Noah built an altar before the Lord - it is the altar which Adam built at the time he was banished from the Garden of Eden and on which he offered an offering, and upon which Cain and Abel offered their offerings. But when the waters of the flood came down it was destroyed. Noah rebuilt it.

Now I will not bother to outline further reasons for reading Matthew 5:21-24 in the light of Genesis 4:1-16. What I want to stress is that after I first found this reading in Cyprian, I went looking for it elsewhere. Initially I came up empty. This was because none of the many modern commentaries then in my personal study seconded Cyprian's interpretation. ${ }^{2}$

\footnotetext{
1.As I once observed: The action depicted by Matthew's words is ... arresting because one cannot really imagine someone doing it. Could one, without causing offence or disturbance, really leave a sacrifice in the hands of the priest or on the altar and go (perhaps to Galilee) and make search for a brother and then, some time later, return to the temple and pick up where one left off, with everything in order and the priest waiting? (cf. Davies \& Allison1988-1997, 1:518)

2.It later showed up in Betz 1995:219 n. 163: 'the great example' in the biblical tradition of anger leading to murder 'is the brothers Cain and Abel: Gn 4:5'; 224 n. 205: if ' $1 \mathrm{Sm}$ 29:4 shows David taking the initiative in getting reconciled with the angry Saul', then 'the opposite is Cain in Gn 4:5-8'; 230 : 'the source of murder is a broken relationship with the brother. The famous case of Cain's murder of his brother Abel (Gn 4:8-16) comes to everyone's mind [sic!], although it is not mentioned in the text'. Whether these comments are independent of what I wrote in my commentary on Cain and Abel and Matthew 5:21-24 (cf. Davies \& Allison 1988-1997, 1:510), I do not know. Betz does, however, list my work in his bibliography.
} 
So I had to leave my study and look through larger libraries in order to discover whether Cyprian was alone or not. I then discovered that he was not alone, but only because I went back in time, because I closed the covers of the contemporary volumes and travelled to the past. I discovered that Cyprian had company. Like-minded readers include the scripturallysaturated Tertullian as well as Chrysostom, Chromatius, Geoffrey of Babion, Paschasius Radbertus, Rupert of Deutz, Hugh of St-Cher, Albert the Great, Hugo Grotius, and Matthew Henry (full documentation in Allison 2005:65-78). So in agreeing with Cyprian about Matthew 5:21-24, I had company.

I have no idea, let me add, and still have no idea, why Matthew Henry appears to be the end of the line for this interpretation. The disremembering of the traditional reading is all the more puzzling because Henry himself was such an influential commentator. One expects that, when sensible proposals appear in his exposition, they will live on. From what I have been able to learn, and for whatever reason, this reading did not.

I come now to a second discovery. This one I missed when I worked my way through Matthew for the first time, writing my commentary. I learned of it only years later. It has to do with the notice, found twice in Matthew, once in Mark, and once in Luke, that people were healed by touching the fringe of Jesus' garment (Mt 9:20; 14:36; Mk 6:56; Lk 8:44).

Once, after finishing a lecture on Matthew, a student asked me to listen to a tape of sermons by his former pastor. I did not want to stifle his enthusiasm, so I thanked him and kindly indicated that I would give a listen, not really intending to do so. But I did end up listening to a few minutes of each side of the tape. All of it was forgettable, except for one thing. The pastor shared what was to me a novel explanation of why the synoptics claim that people were healed by touching 'the hem' of Jesus' garment. Jews, the pastor explained, can refer to the fringes of their garments, or to the edge to which those fringes are attached, with a word, kanaph, whose first meaning is 'wing'. He then went on to observe that the early Christians thought of Jesus as the fulfilment of an oracle at the very end of the Tanak, Malachi's prophecy that the sun of righteousness will arise with healing in his wings (Ml 4:2). The Gospels, the cassette declared, are interested in Jesus' tassels because they care about Malachi's prophecy: Jesus, 'the sun of righteousness', literally had healing 'in his wings', in his hanging fringes.

I had never before run across this idea, which I knew was not in any of the modern critical commentaries. Yet I did not pursue the matter any further until, a bit later, I happened to be reading the so-called Testimony book falsely attributed to Epiphanius, a 4th-century Greek collection of Old Testament prophecies supposedly fulfilled in the life of Jesus. In the middle of this ancient text I ran across the following unelaborated claim: 'That the fringe of Jesus' garment would heal - Malachi says: "to those who fear his name, the sun of righteousness rises having healing in his wings"' (Ml 4:2; cf. Hotchkiss 1974:5). This got my attention. My student's pastor had somehow been promoting an ancient interpretation of which I had had no knowledge.

This was enough to motivate investigation, and soon enough I found the following in Photius (p. 505b.3), the 9th-century lexicographer: "'For", it says, "the sun of righteousness will arise upon you who fear my name, and healing will be in his wings". The sun of righteousness is the Lord of good things, and the wings are the tassels of his garment.' This is exactly the equation that explains Pseudo-Epiphanius' proof-texting five centuries earlier, and exactly the interpretation of my student's former pastor 1000 years later.

I did not think it likely that a modern pastor, a medieval philologist, and the unknown author of an obscure, uninfluential 4th-century testimony collection all worked upon the same exegetical idea independently of each other. I deemed it much more likely that there was some sort of interpretive tradition here, and I imagined that, if I looked hard enough, I would be able to uncover it. Here follows what I found.

This same reading of Malachi and the relevant synoptic verses appear in a Byzantine text of uncertain date falsely assigned to Chrysostom as well as in a sermon on Mary, also of uncertain date, attributed to Hesychius of Jerusalem. ${ }^{3}$ Then, passing through the centuries, I further discovered this interpretation in Hugo Grotius (1679:103), Matthew Poole (1846, 2:1029), Matthew Henry (n.d.: ad loc) - three pretty big names - and in a couple of Protestant commentaries from the 18th and early 19th centuries (Elsley 1844:124; Wordsworth 1864:53). After that, I determined, this interpretation had died out, so that the one place you cannot find it is in the higher-critical commentaries of the last 150 years.

As with Matthew 5:21-24 and Cain and Abel, I have not been able to learn why this old intertextual linking of Malachi 4:2 to the synoptics fell out of favor. I find it truly puzzling given that its proponents include four major exegetical players, namely Photius, Grotius, Poole, and Henry. I have also been unable to document its existence before Ps.-Ephraem's Testimony book. But surely it predates that source. For one thing, the Testimony book is mostly a collection of conventional proof texts, not a creative presentation of new ideas. For another, this book was, to my knowledge, not one of antiquity's best sellers, so there is little reason to posit that the other Greek witnesses to our exegetical tradition all derive from it, directly or indirectly.

3.Ps.-Chrysostom states: Concerning the sun of righteousness, Isaiah [sic] cries out saying: In those days the sun of righteousness will rise, and healing will be in his saying: In those days the sun of righteousness will rise, and healing will be in his wings. For when Christ, the sun of righteousness came, the women with a flow of blood touched the wing of his garment and the fountain of blood was dried up. (PG 55:600)

Hesychius of Jerusalem declares: Malachi [prophesied]: 'The sun of righteousness will rise upon you who fear my name, and healing will be in his wings'. And [this concerns] the matter of the woman with an issue, who was healed after many years ... who received healing by fastening onto the hem (sec. 202). 
I am, furthermore, inclined to suppose that this interesting reading was first made in a Jewish Christian environment, where someone familiar with Jewish customs could think of the tassels of a garment as its wings, as kanaphem. Interestingly enough, my student's former pastor, as it turns out, had gotten his interpretation from modern Hebrew-reading messianic Jews who, independently of Christian exegetical tradition, had reforged the link between Malachi and the synoptics, and then published it a dozen places on the Internet.

Now whether or not Matthew, Mark and Luke had Malachi in mind, surely this is a reading that should be returned to the commentaries (cf. further Allison 2008).

My next example of a suggestive reading that modern Matthean exegesis has forgotten, concerns the missionary discourse in Matthew 10 and its parallels in Mark 6 and Luke 9 and 10, where Jesus forbids his disciples to take several items with them.

Matthew says that the disciples should not take gold, silver, copper, wallet, two shirts, sandals, or staff. Mark says that they should not take bread, wallet, copper, or two shirts (he allows the staff and sandals). Luke 9 and 10 together disallow taking staff, wallet, bread, silver, or purse. No synoptic theory can explain all of these variants; they remain puzzling on any account. For my purposes, however, that does not matter. What I wish to stress here is that the list of items prohibited in Matthew is strikingly reminiscent of one aspect of the biblical story of the exodus from Egypt. Exodus 12 recounts that Moses commanded the Israelites to eat the Passover hurriedly, with sandals on their feet and staff in hand, and that they went forth with bread, with silver, with gold, and with clothing (Ex 12:11, 34-36). Deutoronomium 8:4 and 29:5, moreover, relate that the Israelites' clothing was indestructible, so that they only needed one pair of sandals and one set of clothes. Is it only coincidence that Jesus' disciples are similarly in a hurry but still more so and that they take even less than the fleeing Israelites? Maybe implicit in Matthew is a contrast: what Moses allowed, Jesus prohibited. Certainly elsewhere the first Gospel is much interested in drawing parallels and emphasising contrasts between the history of Jesus and the history of the exodus (Allison 1993). Moreover, several times Matthew's Jesus reverses what the law-giver commanded. Moses said: Honor your father and mother (Ex 20:12; Dt 5:16). Jesus says: Hate your father and mother (Mt 10:37). Moses permitted divorce in the case of a man finding 'something objectionable' about his wife (Dt 24:1). Jesus narrows that allowance considerably (Mt 5:31-32; 19:1-10). Moses commanded: An eye for an eye and a tooth for a tooth (Ex 21:24; Lv 24:20; Dt 19:21). Jesus demands an alternative (Mt 5:38-42).

If I were the only one in exegetical history to set Jesus' prohibitions to missionaries over against the story of the exodus, the exercise would not be worth much. But I did not invent this intertextual proposal. I found it in the church fathers. Here follows Tertullian:
When the children of Israel went out of Egypt, the creator brought them forth laden with their spoils of gold and silver vessels, and with loads besides of raiment and unleavened dough; whereas Christ commanded his disciples not to carry even a staff for their journey ... Consider the difference presented in the occasions and you will understand how it was one and the same power that arranged the mission of his people according to their poverty in the one case and their plenty in the other. Even shoes he forbade them (the disciples) to carry. For it was he under whose protection the people wore out not even a shoe (Deut. 29:5), even in the wilderness for the space of so many years. (Adv. Marc. 4:24)

Ambrose (Traité sur l'Évangile de S. Luc 7:57-60) and Isho'dad of Merv (Comm. Mt. 7) said very similar things; and then there is the (early 4th century?) exegesis of the Marcionite Megethius, who wanted to contrast the God of Jesus with the God of Moses:

The God of Genesis commanded Moses in the going up from Egypt saying, 'Make ready with loins girded, having sandals on feet, staffs in your hands, and traveler's bags upon you. Carry away the gold and silver and all the other things of the Egyptians'. But our good Lord, sending his disciples out into the world, says, 'Neither sandals on your feet, nor traveler's bag, nor two cloaks, nor money in your belts. See how clearly the good one opposes the teachings of that one'. (quoted in Van de Sande Bakhuyzen 1901:22)

This is a very suggestive comment, and I think there may be something to it. But when one leaves the church fathers, the movement from Matthew 10 or its parallels to the exodus all but disappears, at least to the extent of my researches. (It has recently reappeared, independent of my own work, in Marcus 2000:388-89). Why it does so, is unknown to me. Yet, whatever the reason may be, I submit that this is only one more exegetical possibility that should be unearthed and returned to the commentary tradition so that modern scholars can consider it (cf. further Allison 2000:41-43).

I now come to a fourth example of exegetical amnesia. It has to do with Matthew 22:34-40, where a lawyer asks Jesus the following:

'Teacher, which is the great commandment in the law?' Jesus' answer is: 'You shall love the Lord your God with all your heart, and with all your soul, and with all your mind. This is the great and first commandment. And a second is like it, You shall love your neighbour as yourself. On these two commandments depend all the law and the prophets.'

In his review of the history of interpretation of this passage, Luz (2005:77-81) concentrates on five questions: How is 'loving God' to be understood?; Who is 'the neighbour' and what does 'love one's neighbour' mean?; How are the two great commandments related?; How do the law and prophets depend or 'hang' upon those two commandments?; and How new within the context of ancient Judaism is their combination?

Luz's answers to these questions are instructive and insightful, and I do not wish in any way to detract from what 
he has to say. But his Wirkungsgeschichte unexpectedly fails to highlight something that is potentially very important, namely that the Christian tradition has incessantly understood the two great commandments to summarise the Decalogue. This interpretation appears in the current Catechism of the Catholic Church, the 1928 Book of Common Prayer, the systematic theologies of Thomas Watson (1692) and John Gill (1769-1770), the works of Matthew Henry (1662-1714) and Jonathan Edwards (1703-1758), the commentaries of Matthew Poole (1624-1679) and Cornelius à Lapide (1562-1637), the Heidelberg Catechism (1562) and the Westminster Confession (1646-1647), and still earlier, the writings of John Calvin (1509-1564), Thomas Aquinas (12251274), and Rabanus Maurus (776-856) - full documentation and references in Allison (2005:158-1559).

All these regard the imperative to love God and neighbour as the Decalogue in brief. From this cloud of witnesses let me quote the old Book of Common Prayer (1945):

Question: You said that your Sponsors did promise for you, that you should keep God's Commandments. Tell me how many there are?

\section{Answer: Ten.}

\section{Question: Which are they?}

Answer: The same which God spake in the twentieth Chapter of Exodus, saying, I am the LORD thy God, who brought thee out of the land of Egypt, out of the house of bondage. (p. 579)

There follows a recitation of the ten commandments, after which is this exchange:

Question: What dost thou chiefly learn by these Commandments?

Answer: I learn two things; my duty towards God, and my duty towards Neighbour.

Question: What is thy duty to God?

Answer: My duty towards God is To believe in him, to fear him, and to love him with all my heart, with all my mind, with all my soul, and with all my strength (cf. Dt 5, 6).

Question: What is thy duty to thy Neighbour?

Answer: My duty towards my Neighbour is To love him as myself (cf. Lv 19, 18) ... (p. 579).

How old is this idea? It appears already in the fourth century, in the Apostolic Constitutions (2:36), and an even earlier witness is Irenaeus, at the end of the 2nd century. He says that 'the meaning of the decalogue' was 'written in the hearts and souls' of the patriarchs, which means that 'they loved the God who made them and did no injury to their neighbour'. He also affirms that, when the Israelites received the ten commandments, the purpose was to enjoin 'love of God' and to teach 'just dealings with our neighbour' (Adv. haer. 4.16.3).

Luz's surprising failure to call attention to this ubiquitous tradition is mirrored in the silence of the other modern commentaries on Matthew (although since the publication of Davies \& Allison 1988-1997, 3:238, this may be changing; cf. Marcus 2009:839; Nolland 2005:909). Perhaps modern ideology has played its role here. Maybe our post-Kantian preference for general principles over concrete imperatives disinclines us to relate the generalisations about God and neighbour to the more specific imperatives in the Decalogue. The double commandment to love is certainly easier to bend to our purposes than the ten commandments.

However that may be, the omission bothers me because I think it is possible that the old ecclesiastical idea would not have been foreign to Matthew or his first readers, that the double commandment to love might have struck the ancients as a conventional summing-up of the 10 commandments. Philo believed the Decalogue to be a sort of abstract of the entire mosaic legislation, and he also thought that the Decalogue itself can be summarised, that the ten words can in fact be reduced to two. As have so many since, he divided the ten commandments into 'two sets of five, which he [God] engraved on two tables' (Decal. Sec. 50; cf. sec. 106). The first set of five, each one of which mentions the divine name, prohibits having other gods, making graven images, and taking the Lord's name in vain whilst it enjoins Sabbath observance and honoring parents. The second set of five, none of which mentions God's name, consists of the prohibitions of adultery, murder, theft, false witness, and covetousness (sec. 51).

Philo's twofold division, likewise attested in Josephus, is more than formal. The partitioning is also thematic. The first set of injunctions are, he says, 'more concerned with the divine' (sec. 121). The second set has to do with 'the duties of individual to individual' (sec. 106). This twofold explication, with its focus on duty to God and to humanity, brings us near Matthew's Jesus.

But there is more. Philo summarily characterises the two chief duties in terms of love (Decal. Sec. 108-110). Those who observe the 1st five words are 'lovers of God'. Those who observe the 2nd five words are 'lovers of people'. This interpretation, which is offered as though obvious, makes plain that the summary of the Torah, the Decalogue, may itself be summarised by two demands, the demand to love God and the demand to love the neighbour. The parallel to Matthew 22 is all the closer because if, in Philo, the commandments concerning love of God are the first set and those concerning love of humanity are the second set, in Matthew love of God is the first commandment and love of the neighbour the second commandment. Philo at least would have construed the commandments to love God and the neighbour as a synopsis of the Decalogue, a resume of the two tables given to Moses.

I cannot here introduce the additional reasons for inferring that others beside Philo might have understood Matthew 22:23-30 along the lines indicated. I trust, however, that I have said enough to demonstrate that here is yet one more example of something one finds in old books that should also be in the newer books. 


\section{Intertextuality}

If the history of interpretation has been a bit of a fad over the past 25 years or so, the same is true of work on New Testament intertextuality. Books and articles on how the New Testament quotes and echoes and alludes to the Old Testament have multiplied during that time. Now there is no necessary connection between these two approaches, and I suppose that, in most people's minds, they are independent disciplines. For me, however, the one is indispensable for the other. Let me explain.

Richard Hays (1989:29-32), in his well-known book on Echoes of Scripture in the letters of Paul, outlines several criteria by which one may come to the conclusion that one deliberately alludes to another. One of them is history of interpretation, which makes sense. If text $A$ has, through the centuries, reminded commentators of text $\mathrm{B}$, then the odds that it was designed to do so are enhanced. And if commentators have uniformly missed an allusion, doubt may be appropriate.

Yet Hays finds the history of interpretation less than reliable. Hays' (1989) justification is this:

Gentile Christian readers at a very early date lost Paul's sense of urgency about relating the gospel to God's dealings with Israel and, slightly later, began reading Paul's letters within the matrix of the New Testament canon. This criterion should rarely be used as a negative test to exclude proposed echoes that commend themselves on other grounds. (p. 31; yet contrast Hays 2002:il-li).

I am of another mind. It is true enough that Christian commentators have always moved from one New Testament text to other New Testament texts. Thus Luke 10:21-22 ('No one knows the Son except the Father, and no one knows the Father except the Son') has most often been linked with verses from John (e.g. 1:18: 'No one has ever seen God. It is God the only Son ... who has made him known'); and the text most commonly called upon to elucidate Matthew 24:40 ('one will be taken and one will be left') has been 1 Thessalonicense 4:17 ('Then we who are alive, who are left, will be caught up in the clouds'). It is equally true, however, that many Christian exegetes have lived and moved and had their being in the entirety of the Bible, that they have known the Scriptures inside out. In some cases, moreover, ecclesiastical circumstances have encouraged Christian readers to search for First Testament parallels to Second Testament texts. Thus Tertullian, in his implacable opposition to Marcion, who denied that the New Testament deity is the Old Testament deity, became one of the most accomplished, astute intertextual readers in Christian history. It was in Tertullian's theological interest to find as many correlations as possible between the two Testaments.

In my own intertextual work on Matthew, I have in fact come to rely on Tertullian a great deal. I have also come to trust Albert the Great, whose commentaries on the gospels are unparalleled treasure troves of possible intertextual connections (cf. Geyer 1951ff.). Another helpful guide has been Hugo Grotius (1679). In fact, if a New Testament text causes all three of these interpreters to think of a particular Old Testament text, then in my experience serious investigation is in order, no matter what the modern commentators say. And when these three fail to be put in mind of an intertextual link that some modern scholar has suggested, then it is going to take a great argument to get me to depart from their company. Their agreement is for me a weighty fact.

I can illustrate how this works by reverting to some of the interpretive suggestions I made earlier in this article. Regarding the proposal that Matthew 5:21-24 alludes to the story of Cain and Abel, all three of my intertextual guides here find Genesis in the Sermon on the Mount. The upshot is that I have a great deal of confidence that I am right about this. It is otherwise when it comes to associating the hem of Jesus' garment with the end of Malachi. It is only Grotius who hears a prophetic echo in the synoptic phrase, so here my confidence is lessened. Having Grotius on my side is encouraging, but the silence of Tertullian and Albertus gives me pause. Things are even worse with respect to the possibility that Jesus' prohibition of gold, silver, copper, wallet, two shirts, sandals, and staff in Matthew 10 reverses an event in Exodus. I have been unable to find this exegetical idea in Tertullian, Albertus, or Grotius. So my sense is that, however intriguing and otherwise inviting this possibility is, it remains nothing more than a possibility. If my three witnesses do not see what I see, I asume that it is not really there.

Before moving to the next section, I would like to qualify my enthusiasm for using the history of interpretation as an aid in determining the presence or absence of intertextuality. Although I am more enthusiastic about the utility of earlier interpreters than is Hays, my enthusiasm is not unqualified. There are times when I think it possible that Matthew intended an intertextual link that the commentary tradition has missed. I offer two illustrations.

The first has to do with Matthew 5:1-2. I am quite confident that, when Matthew made Jesus sit on a mountain before delivering the great sermon in chapters $5-7$, he intended a parallel with Moses. Not only do the previous four chapters develop an extensive Moses typology (Allison 1993), but there are linguistic parallels between the opening and closing of the sermon on the mount and pentateuchal texts about Moses ascending Sinai and coming down therefrom (Allison 1993:174-175, 179-180). One assents then when Matthew Henry (n.d.:5:ad loc.) writes: 'Christ preached this sermon, which is an exposition of the law, upon a mountain, because upon a mountain the law was given.'

But whilst this thought is at home in the commentary, nobody to my knowledge associated Jesus' sitting with the posture of Moses on Sinai. There was, however, a Jewish tradition that Moses sat on the mountain. It was based upon Deuteronomium 9:9, where Moses speaks these words:

When I went up the mountain to receive the tables of stone, the tables of the covenant which the Lord made with you, I remained 
on the mountain forty days and forty nights; I neither ate bread nor drank water.

The Hebrew here translated as remained can also be translated as sit, and it is so rendered in b. Meg. 21a: 'One verse says, "And I sat in the mountain" [Dt. 9:9], and another verse says, "And I stood in the mountain"' [Dt. 10:10]. Rab says: 'He [Moses] stood when he learned and sat while he went over [what he had learned]'. R. Hanina said: 'He was neither sitting nor standing, but stooping.'

Now what matters for Matthew is that the tradition that Moses sat on Sinai was established in pre-Christian times. The proof of this I have detailed elsewhere (Allison 1993:175-179). The point here, however, is that the image of Moses sitting on Sinai appears never to have entered the mainstream Christian tradition. I have not found it in the church fathers or in later Christian texts. Certainly the commentary tradition does not know it. So here is a case where I can get no help from the history of interpretation, or rather a case in which I see something that the commentary tradition in its entirety does not. The explanation is that I am acquainted with a Jewish tradition that my Christian predecessors did not know about.

Mysecondillustration of thelimits of thehistory of interpretation for intertextual investigation has to do with Matthew 16:13-20, the episode of Peter's confession of Jesus as Messiah and Son of God. Years ago I began to toy with the notion that the Peter of Matthew 16 can be profitably understood as a sort of new Abraham. Of the Old Testament figures who receive a second name, the most memorable are Abram and Jacob. The former was given the new name Abraham to signify that he would be the father of a multitude (Genesis 17:1-8), and the parallels between Genesis 17 and Matthew 16 are quite intriguing. In both cases we are witnessing the birth of the people of God, the Jews in the one case, the church in the other. In both, that birth is associated with one particular individual - Abraham, then Peter. And in both that individual has a name which symbolises his new crucial function. Abraham is taken to mean 'father of a multitude', Peter to mean the 'rock' on which the church is founded.

I was encouraged in this inference by Isaiah 51:1-2:

Hearken to me, you who pursue deliverance, you who seek the Lord; look to the rock from which you were hewn, and to the quarry from which you were digged. Look to Abraham your father and to Sarah who bore you; for when he was but one I called him and I blessed him and made him many.

Here Abraham, like Peter, is a rock. So just as the Old Testament figure whose name was changed in order to signify the coming into being of the people of God was likened to a rock, so too in Matthew is the birth of the church accompanied by Simon gaining the new name, Peter.

I was also encouraged by a passage in a very late Jewish text, Jalqut Shimon I § 766, on Numbers 23:9. This says: when God 'saw Abraham who was going to arise, He said, Behold, I have found a rock (pîtrā') upon which to build and establish the world. Therefore he named Abraham a rock (sûr)' (cf. Is 51: 1-2). One suspects Christian influence because of the lateness of the text and the use of the Greek loanword, pitrā. Yet, if this supposition is correct, this only goes to show how the rôles of Peter and Abraham lent themselves to comparison.

The history of interpretation, however, is here disappointing. I did find a few patristic texts that mention the switch from Simon to Cephas or Peter alongside the switch from Abram to Abraham (e.g. Origen, Orat. 24.2; Eusebius, Comm. Is 2.37; Gregory of Nyssa, Cant. 15; John Chrysostom, Educ. lib. 670); but none of them involve exegesis of Matthew 16:13-20, and none of them understand Peter as something like a new Abraham. So I came up empty, and although my proposal gained a few sympathetic responses (e.g. Boxall 2014:139), I had to wonder whether I was seeing things. At some point, however, a light went off, and I came to think that I might be able to explain the silence. I had been reading Matthew against the background of the Old Testament and Jewish tradition. But the Christian commentators through the ages had been reading Matthew 13:16-20 also within its New Testament canonical context. This means that every one of them was, when interpreting Matthew 16, thinking of the beginning of the ministry in John 1:40-42:

One of the two who heard John speak, and followed him, was Andrew, Simon Peter's brother. He first found his brother Simon, and said to him, 'We have found the Messiah' (which means Christ). He brought him to Jesus. Jesus looked at him, and said, 'So you are Simon the son of John? You shall be called Cephas' (which means Peter).

This explains the remark of Matthew Poole (1846, 3:76) on Matthew 16:18: 'Christ gave him this name [Peter], John i.42, when his brother Andrew first brought him to Christ. I did not give thee the name of Cephas, or Peter, for nothing I called thee Cephas, and thou art Peter, a rock.'

In John's Gospel, Peter receives his new name at the very beginning of the public ministry, and without any connection to Jesus founding the church. So if, with the older, harmonising exegetes such as Poole, one reads Matthew 16 within its broader New Testament context, one does not associate the birth of the church with Peter receiving his new name; the two events remain separate. This, then, might be the reason why there appears to be no precedent in exegetical tradition for the proposed parallel between the Peter of Matthew 16 and the Abraham of Genesis 17.

\section{Multiple meanings}

So far I have recounted how attention to the history of interpretation has both acquainted me with interesting readings absent from our contemporary literature and given me guidance when I have been exploring intertextual connections. I now come to my third point, which is that Wirkungsgeschichte has helped me to fathom the inherent ambiguity of texts and their potential multiple meanings. 
When I was in graduate school, I learned historical-critical methods. I was given the tools by which to understand, in its original Sitz im Leben, whatever old text I happened to be studying. This meant in practice divining some combination of what an ancient author probably intended and what an ancient audience might have thought. Nobody warned me about the intentional fallacy, and nobody taught me about the indeterminate nature of texts.

Early on then I picked up the habit of sorting through exegetical proposals, trying to figure out which one was correct, that is, which one was most likely to occur to a firstcentury author or audience. Soon enough, however, I did learn how old-fashioned this was, at least as an exclusive pursuit, in terms of modern hermeneutics and modern literary theory. Yet given my history, I was resistant. The idea of that a text might have indeterminate meaning or multiple meanings seemed to place a large question mark over how I had been accustomed to do business.

Two things gradually lead me to modify - not give up, but to modify - the view I had when I left graduate school. One was the experience of writing a commentary and, on various occasions, discovering that more than one interpretation made sense to me and, secondly thinking that more than one interpretation might have made sense to an ancient author or audience. For example, when I studied the debate as to whether the beatitudes in Matthew 5 are implicit imperatives and so moral - you should be meek, you should pure in heart, and so on - or whether they are promissory and conciliatory you will be comforted, you will see God - I saw no need to make a choice. Why not both at the same time, or one or the other depending upon a hearer's immediate circumstances?

Again, when looking at Matthew 28:9, where Mary Magdalene and the other Mary grab Jesus' feet, I discovered several exegetical options. Some took the woman's physical act to be a sign of their joy and affection. For others it betokened submission. For others it was an act of worship. For still others - the majority view - the act carried apologetical meaning: if Jesus had feet, he could not have been a ghost (just as he cannot be a ghost at the end of Luke and at the end of John, where he invites others to touch him). But it seemed to me that more than one of these readings might naturally occur to someone at the same time. Why, then, choose one over the other if all make good sense in the literary context?

The other thing that helped me modify my quest for the one true meaning was the slow realisation that the older commentators were quite often content not to choose. I do not refer here to the classical idea of the four-fold meaning of Scripture - literal, allegorical, moral, and anagogical. I refer rather to older writers who sometimes list the various interpretive options and deem them all appropriate. Consider for instance what the old Baptist theologian John Gill (1980) had to say about the women grabbing Jesus' feet in Matthew 28:19:
They threw themselves prostrate at his feet, in token of reverence and humility; and they laid hold on his feet, that they might know, and be assured that he was really risen, and that it was not a spirit, or a mere phantom and appearance; and they held him in affection, and as desirous of his continuance with them. (p. 303)

Here are the several meanings I listed above, presented not as alternatives but compliments (note also Sedulius Scottus, Comm. Mt ad loc., ed. Löfstedt:636-37; Dionysius bar Salibi, Expl. Evang. ad loc. CSCO 77, Scriptores Syri 33, ed. Sedlaeck \& Chabot:160; Euthymius Zigabenus, Comm. Mt ad loc. PG 129.758A).

Contrast this with what one finds in Luz's (2005:607) commentary. According to him, the women's act of grasping Jesus' feet is one of homage, and thus there is no emphasis upon the corporeality of Jesus' resurrection. This objection seems to assume that the interpreter must choose between homage and apologetics: the text cannot serve the latter if it expresses the former. Eduard Schweizer (1975:525) betrays a similar antithesis when he writes that the women touching Jesus' feet 'is not yet meant to counter false notions of the resurrection; it grows quite naturally out of the narrative' - as though something that grows naturally out of the narrative could not simultaneously serve, or is less likely to serve, an apologetical purpose. I do not understand their verdicts. Who passed the hermeneutical law that a text must, like a one-way street sign, send us in one direction only?

Gill did not know about this law, and I suggest that we should not feel compelled to choose between the several interpretations of Matthew 28:9. Affection, submission, and worship readily belong to one and the same act; and that the notice of people grasping Jesus' feet could additionally serve an apologetical end is scarcely far-fetched.

Let me offer one more illustration of a text which I think should send us in several directions at once. When Jesus dies in Matthew 27, the sun goes dark, from the 6th until the 9th hour. In addition to the several intertextual and intratextual possibilities here, one finds the following five ideas in the commentary tradition: the darkness is the proof of divine judgement; is a sign that God and/or nature mourns the crucifixion of God's Son; indicates that Jesus' death is the end of the world in miniature or a proleptic anticipation of the end; show us that nature was so ashamed of the cross that it refused to behold the sight; and communicates the cosmic scope of Jesus' death. So which reading is correct?

None of them seem antagonistic to me; that is, I see nothing in one idea that disallows another. On the contrary, they seem closely related. For example, the theme of judgement hardly crowds out the theme of mourning or vice versa; and cosmic meaning scarcely cancels the eschatological reading; in fact, the latter seems to imply the former.

The commentary tradition comes to our aid here, because exegete after exegete refrains from insisting on finding a 
single connotation here. Even Calvin (1972, 3:207) atypically lists several options without rebuting them and then goes on to give his own view. Evidently he finds them all sensible. Bengel (1850:118) speaks of 'three hours full of mystery', and surely an element of the mystery is the plentitude of meaning in the lack of light. But once again Gill (1980) supplies me a quotation that illustrates my point. In his words, the sun was:

... hiding its face, and refusing to afford its comforting light and heat to him [Jesus]; and yet [its act] might be in detestation of the heinousness of the sin the Jews were committing, and as expressive of the divine anger and resentment; for God's purposes and decrees, and the end he had in view, did not excuse, nor extenuate their wickedness It was an emblem of the judicial blindness and darkness of the Jewish nation; and signified, that now was the hour and power of darkness, or the time for the prince of darkness, with his principalities and powers to exert himself: and was a representation of that darkness that was now on the soul of Christ, expressed in the following verse; as well as of the eclipse of him, the Sun of righteousness, of the glory of his person, both by his incarnation and by his sufferings. (p. 295)

I have come more and more to think that this sort of nonexclusive interpretation often corresponds to how a text was intended to be heard and was heard from the beginning.

\section{The problem of presuppositions}

I now come to my last major point, which is that paying attention to older commentaries often helps us to see how our own presuppositions get in the way of reading texts from 2000 years ago. Here I offer in illustration my work on the star of Bethlehem.

When I began, many years ago, working on Matthew's infancy narrative, Raymond Brown's (1993), The birth of the Messiah, was my constant companion. It taught me much, and I considered it then and consider it now to be a great book. But I remember two experiences that gave me pause and made me realise it could not be my only guide. First, at some point I decided, for reasons I can no longer recall, to pull down from the shelves of the local library some German commentaries written before the 20th century. Before doing that, the earliest commentaries I had looked at were probably those of W.C. Allen (1912) and A.H. McNeile (1915). What I discovered, to my surprise and confusion, was that most, not all but most of the exegetical opinions in Brown were already there in the 19th century German writers, and with most of the same arguments pro and con whatever the issue. I was not expecting this, because my education had implicitly taught me that the newest was not only the best but also truly new. I began to have doubts.

Even more important was my experience with the star of Bethlehem in Matthew 2. Brown devoted a couple of pages to discussing the historical issue. He asked, if there is some memory here, what real-life event might have inspired Matthew's story? He dutifully catalogued the three common modern explanations. Maybe Matthew's star was really a supernova, or maybe it was a planetary conjunction, or maybe it was a comet. Now as I pondered these options, none of them made much sense. The text relates that the star 'went before' the magi, and likewise that 'it came to rest over the place where the child was' (Mt 2:9). This is beyond peculiar if the object is astronomical. Comets of course traverse the sky, and supernovas and conjunctions, because of the earth's motion, at least appear to move. But that a lighted object high in the sky above could guide someone on the earth below to a precise location just does not compute.

I do not know what I would have thought unless I had come upon a passage in Chrysostom (Homilies on Mt 6:3). But I did, and I read this: Bethlehem's star:

... did not, remaining on high, point out the place, it being impossible for ... [the magi] so to find it; instead it came down and performed this office. For you know that a spot as small as that taken up by a shed or by the body of a little infant, could not possibly be marked out by a star. For by reasons of its immense height, it could not sufficiently distinguish so confined a spot, and reveal it to those wanting to see it.

This set me to thinking, because Chrysostom is right - 'by reasons of its immense height, it could not sufficiently distinguish so confined a spot, and reveal it to those wanting to see it' $^{\prime}$ - and this made me wonder what exegetical history might have to say. Soon enough I ran across this, in the Protevangelium of James: 'And the magi went forth. And behold, the star which they had seen in the east went before them, until they came to the cave. And it stood over the head of the child. And the magi saw the young child with Mary his mother ...' (21:3). Here, as in Chrysostom, the star is unattached to the firmament, and it descends and leads the way until it rests right over Jesus' head.

The 3rd text I ran across was in the so-called Arabic gospel of the Savior (which may be as early as the 5th century). Its 7th chapter relates the following:

And it came to pass, when the Lord Jesus was born at Bethlehem of Judea, in the time of King Herod, behold, magi came from the east. And there were with them gifts of gold, frankincense, and myrrh. And they adored him [Jesus], and presented the gifts to him. In the same hour there appeared to them an angel in the form of that star which had before guided them on their journey; and they went away, following the guidance of its light, until they arrived in their own country.

I no longer remember in what order I discovered the other relevant sources, but what I learned was this: The notion that the star actually left its distant abode and descended to earth, and thereupon led the way straight to the infant Jesus, until it entered the stable in which he was and came to rest right over his head, is all over the pre-Renaissance literature. It is in Irenaeus, Origen, Ephraem the Syrian, Augustine, Basil the Great, Gregory of Nyssa, Peter Chrysologus, Ishodad of Merv, Fulgentius, Dionysius Bar Salibi, Theophylact, and a host of others, up to and including Luther and Calvin (full documentation in Allison 2005:17-41). The latter (Calvin $1972,1)$ saw the obvious, namely that: 
... it was not a natural star, but extra-ordinary, for it was not of the order of nature to disappear at certain times, and afterwards suddenly to shine again. Further, that it led in a straight path to Bethlehem, and at length stood fixed over the place where Christ was. None of this accords with natural stars. (p. 83)

As late as the early 17th century, Lapide (2008, 1:58-59) could affirm that this idea of a free-floating, guiding light was 'the common opinion of believers'. He even records the incredible legend, attributed to Gregory of Tours, that the star eventually descended into a well and extinguished itself (cf. Trapp 1865:11).

I further discovered that the Arabic gospel of the Savior was not alone in identifying Matthew's star with an angel. The apocryphal History of the blessed virgin Mary (1:30), an old Syriac text, tells us that 'a Watcher [angelic being] was sent into Persia, and he showed himself to the Persians in the form of an exceedingly brilliant star, which lit up the whole region of the country' (Budge 1899:30). It was this Watcher that the magi followed. One also finds the angelic interpretation of Matthew's star, or acknowledgement of its possibility, in, amongst others, Ps.-Caesarius of Nazianzen, Ps.-Theodotos of Ancyra, Chrysostom, Remigius of Auxerre, Thedore the Studite, Isho'dad of Merv, Theophylact, Solomon of Khilât, Bar-Hebraeus, Thomas Aquinas, and Maldonatus (full documentation in Allison 2005:17-41). It is also pertinent that Christian artistic depictions of the nativity sometimes replace Bethlehem's star with an angel or show both an angel and a star (Cardini 1993:47-48, with plates 3 [the star with a face], 6, 12, 19, 21; Réau 1957:249; Schiller 1971:101-102, with plates $262,269,270,272,275)$.

What I realised after learning all of this - of which there was no trace in Brown's seemingly comprehensive commentary is that this is quite a plausible reading of Matthew's text, certainly far more plausible than trying to tie Matthew's language to a comet or planetary conjunction or a supernova. In the biblical tradition, angels ascend and descend. They are bright. They can serve as guides. And in many texts, stars are indeed angels, which is why, in the Old Testament, the phrase, 'hosts of heaven' sometimes means stars, sometimes angels (cf. Allison 2005:25-28, 36-41). One recalls Job 38:7, where 'the morning stars sang together' is synonymous with 'all the sons of God shouted together'.

To sum up, I had found an interpretation that seemed, at the very least, worth mentioning, but neither Brown nor any of the recent commentaries mentioned it. To find it, I had to go back to the 17 th century and earlier.

How could I explain this; explain the fact that a perfectly plausible interpretation of a gospel passage, an interpretation that was once everywhere, was now nowhere? I eventually discovered that the commentary tradition reflects two wider cultural developments. The first was the condemnation of Origen. Following Plato and Philo, who taught that stars were rational souls; and in their desire to discredit astrology, Jerome and those representing the so-called orthodox churches determined that this was a bad idea, and that it would be better if the heavens were not alive. The Second Council of Constantinople (553 CE) ended the debate: 'If anyone shall say that the sun, the moon and the stars are also reasonable beings ... let him be anathema' (Straub 1971:248).

This obviously discouraged the angelic interpretation of Matthew's star. It did not, however, eliminate it, for it was possible to regard Matthew's guiding light as angelic yet deny that the ordinary stars of heaven were angelic. Theophylact (Comm. Mt ad loc. PG 123.161C), whose orthodoxy was impeccable, could write:

When you hear 'star', do not think that it was a star such as we see, but a divine and angelic power that appeared in the form of a star. The magi were astrologers, and so the Lord used what was familiar to them to draw them to himself. That the star was an angelic power is apparent from the fact that it shone even by day, and that it moved as they moved, and stood still as they rested; also, that it moved from Persia in the north to Jerusalem in the south. For a star never moves from north to south.

Bar Hebraeus, without censorship, or fear of the same, wrote: 'Some say that it was an angel that appeared to them like a star' (quoted by Carr 1925:10). Isho'dad of Merv (Comm. Mt ad loc.) was of like mind:

It is evident from many things that it was not a real star, nor an imagination, nor a fantasy, nor an automaton, but an angel who shone like a star from Persia to Bethlehem. It was not a natural star, but a starry likeness. (sec. 26-27)

So the old view, with a slight revision, lived on until the Renaissance, for it was then that every vestige of the old notion of an animate heaven was finally abandoned and the way was prepared for Copernicus, Galileo, and Kepler to create the modern science of astronomy. The result of their astronomical revolution could have been predicted. Commentators were moved to read their old texts in the light of the new knowledge. And so began the modern debate over whether the star was a comet or planetary conjunction or, most recently, a supernova. The upshot is that, as one moves from Calvin to Brown, from the 17th century to the 20th century, the idea of the star as an angel recedes until the major commentaries no longer speak of it.

My larger point, however, is that modern commentators interpret Matthew 2 with modern presuppositions. They speculate about supernovae, planetary conjunctions, and comets in terms of modern science. It seems never to occur to them that maybe the author of Matthew had very different ideas about the lights in the sky.

\section{Concluding remarks}

In an essay of reflections on writing a large commentary on Matthew (France 2007), France (2008:287) writes that the response of readers to New Testament texts, both within and beyond the New Testament period, are an interesting and potentially significant part of our engagement with 
the text as scripture'. He nonetheless goes on to assert that, in his 'primarily exegetical commentary', 'any significant survey of the history of interpretation would have been an unjustifiable luxury'. He partly justifies the lacuna by appealing to 'the great commentary of Luz' and to 'a job already admirably done'. Luz's work, France confesses, gave him 'a clear conscience' when he refrained from doing his own Wirkungsgeschichte.

France views interaction with the history of interpretation of Matthew as an option, not a necessity. For me, it is the other way around. If one is looking for help in reflecting on one's own modern presuppositions, or in pursuing intertextual questions, or in looking for fresh ideas - and what commentator should not be looking for these things? the supposedly outdated volumes always repay attention. Further, the appeal to Luz cannot serve as a good excuse to ignore Wirkungsgeschichte. As helpful as his work is, it necessarily leaves a great deal, including a great deal of importance, out of account. This article is the proof, because the majority of my interpretive suggestions derive from the history of interpretation as opposed to modern commentaries, and none of them is in Luz. France might as well, to my mind, have confessed that he did not need to undertake the task of exegesis because Luz has already interpreted Matthew. Luz is the beginning of Wirkungsgeschichte of Matthew, not its end.

Of course I do not wish to claim too much. I freely concede that, in some important ways, the old commentaries are not very helpful. If one is interested in whether or not some event recorded by Matthew really happened; or if one is concerned about the textual variants for a certain verse; or if one is trying to understand some theme in Matthew within the context of 1st-century Judaism, the old books will disappoint. Nonetheless, the value of the premodern volumes more than compensates for these limitations.

There is a temptation, as the literature in the field of biblical studies continues to grow at a dismaying rate, to hope that we can ignore old books and old articles. How can one keep up with what is going on now if one is still catching up with what went on then, if one is spending time, let us say, with books from the 4 th, 16th, or 18th centuries? The temptation is all the greater if one's education left the impression that anything of real importance said once will be said again and so not forgotten, or if one has learned that exegesis progresses like the hard sciences, so that today's work makes yesterday's obsolete. But it is not so, and the exegetical past continues to be highly instructive. We should not regard the history of interpretation as a passing fad, or as the sort of thing one can leave to others because it is a luxury. The old volumes hold treasures waiting to be discovered.

\section{Acknowledgements Competing interests}

The author declares that he has no financial or personal relationship(s) that may have inappropriately influenced him in writing this article.

\section{References}

Allen, W.C., 1912, A critical and exegetical commentary on the Gospel according to st. Matthew, 3rd edn., Clark, Edinburgh.

Allison, D.C., Jr., 1993, The new Moses: A matthean typology, Fortress, Minneapolis.

Allison, D.C., Jr., 2000, The intertextual Jesus: Scripture in Q, Trinity Press International, Valley Forge.

Allison, D.C., Jr., 2005, Studies in Matthew: Interpretation past and present, Baker Academic, Grand Rapids.

Allison, D.C., Jr., 2008, 'Healing in the wings of his garment: The synoptics and Mal $4: 2$ ', in J.R. Wagner, C.K. Rowe \& A.K. Grieb (eds.), The word leaps the gap: Essays on Scripture and theology in honor of Richard B. Hays, pp. 132-46, Eerdmans, Grand Rapids.

Aquinas, T., 2009, Catena Aurea: Commentary on the four gospels collected out of the works of the fathers, Baronius Press, London.

Bengel, J.A., 1850, Gnomon Novi Testamentii, vol. 1, Ludov. Frid. Fues, Tübingen.

Betz, H.D., 1995, The Sermon on the Mount: A commentary on the Sermon on the Mount, including the Sermon on the Plain (Matthew 5:3-7:27 and Luke 6:20-49), Fortress, Minneapolis.

Book of Common Prayer, 1945, The Church Pension Fund, New York.

Boxall, I., 2014, Discovering Matthew: Content, interpretation, reception, SPCK, London.

Brown, R.E., 1993, The birth of the Messiah, new updated ed., Doubleday, New York.

Budge, E.A.W., 1899, The history of the Blessed Virgin Mary, Luzac, London.

Calvin, J., 1972, Commentary on a harmony of the evangelists, Matthew, Mark, and Luke, Eerdmans, Grand Rapids.

Cardini, F., 1993, La stella e i re: Mito e storia dei magi, Edifir, Firenze.

Carr, W.E. W. (ed.), 1925, Commentary on the Gospels from the Horreum Mysterium, SPCK, London.

Daillé, J., 1675, A treatise concerning the right use of the fathers, in the decision of the controversies that are at this day in religion, John Martin, London.

Davies, W.D. \& Allison, D.C., Jr., 1988-1997, A critical and exegetical commentary on the Gospel according to saint Matthew, Clark, Edinburgh.

De Maldonatus, J., 1888, A commentary on the holy gospels, Hodges, London.

Elsley, H., 1844, Annotations on the four Gospels and the Acts of the apostles, Vincent, Oxford.

France, R.T., 2007, The Gospel of Matthew, Eerdmans, Grand Rapids.

France, R.T., 2008, 'Reflections on the writing of a commentary on the Gospel of Matthew', in M.G. Daniel \& J. Nolland (eds.), Built upon the rock: Studies in the Gospel of Matthew, pp. 282-289, Eerdmans, Grand Rapids.

Geyer, B. (ed.), 1951, Opera omnia ad fidem codicum manuscriptorum edenda, apparatu critico, notis, prolegomenis, indicibus instruenda curavit Institutum Alberti Magni Coloniense, Münster, Westfalen.

Gill, J., 1980, Gill's commentary, Baker, Grand Rapids.

Grotius, H., 1679, Opera omnia theologica, vol. 2, part 1, Joannis Blaev, Amsterdam.

Gowler, D.B., 2014, James through the centuries, Wiley-Blackwell, Chichester.

Hays, R.B., 1989, Echoes of Scripture in the letters of Paul, Yale University Press, New Haven.

Hays, R.B., 2002, The faith of Jesus Christ: The narrative substructure of Galatians 3:1-4:11, 2nd edn., Eerdmans, Grand Rapids.

Henry, M., n.d., Commentary on the whole Bible, Fleming H. Revell, New York.

Hotchkiss, R.V., 1974, A pseudo-Epiphanius testimony book, Society of Biblical Literature, Missoula.

Joyce, P.M. 2013, Lamentations through the centuries, Wiley-Blackwell, Chichester.

Klancher, N., 2013, The taming of the Canaanite woman: Constructions of Christian identity in the afterlife of Matthew 15:21-28, De Gruyter, Berlin.

Klauck, H-J. et al. (eds.), 2009-2014, Encyclopedia of the Bible and its reception, vols. 1-9, De Gruyter, Berlin.

Künzi, M., 1977, Das Naherwartungslogion Markus 9,1 [i.e. neun eins] par: Geschichte seiner Auslegung, Mohr Siebeck,Tübingen.

Lapide, C.A., 2008, The great commentary of Cornelius Lapide, Loreto Publications, Fitzwilliam.

Lieb, M., Mason, E. \& Roberts, J. (eds.), 2011, The Oxford handbook to the reception history of the Bible, Oxford University Press, Oxford.

Luz, U., 2001, Matthew 8-20: A commentary, Fortress, Minneapolis.

Luz, U., 2005, Matthew 21-28: A commentary, Fortress, Minneapolis.

Luz, U., 2007, Matthew 1-7: A commentary, Fortress, Minneapolis.

Manton, T., 1653, A practical commentary, or, An exposition with notes on the epistle of James: Delivered in sundry weekly lectures at Stoke-Newington in Middlesex, near London, John Macock, London.

Marcus, J., 2000, Mark 1-8: A new translation with introduction and commentary, Doubleday, Garden City.

Marcus, J., 2009, Mark 9-16, Yale University Press, New Haven. 
McNeile, A.H., 1915, The Gospel according to st. Matthew, Macmillan, London.

Meyer, H.A.W., 1885, Critical and exegetical hand-book to the epistles to the Philippians and Colossians, and to Philemon, Funk \& Wagnells, New York.

Nolland, J., 2005, The Gospel of Matthew: A commentary on the Greek text, Eerdmans, Grand Rapids.

Photius, 1825, Bibliotheca, ed. I. Bekker, Reimeri, Berlin.

Poole, M., 1846, A commentary on the holy Bible, Henry G. Bohn, London.

Prigent, P., 1959, Apocalypse 12: Histoire de l'exégèse, Mohr Siebeck, Tübingen.

Réau, L., 1957, Iconographie de l'art Chrétien, Tome Second: Iconographie de la Bible 2: Nouveau Testament, Presses Universitaires, Paris.

Riches, J.K., 2008, Galatians through the centuries, Blackwell, Malden.

Ropes, J.H.R., 1916, A critical and exegetical commentary on the epistle of st. James, Clark, Edinburgh.

Schendel, E., 1971, Herrschaft und Unterwerfung Christi: 1. Korinther 15, 24-28 in Exegese und Theologie der Väter biz zum Ausgang des 4. Jahrhunderts, Moh Siebeck, Tübingen.
Schiller, G., 1971, Iconography of Christian art, volume 1: Christ's Incarnation Childhood Baptism - Temptation Transfiguration Works and Miracles, New York Graphic Society, Greenwich.

Schweizer, E., 1975, The good news according to Matthew, John Knox, Atlanta.

Smith, H., 1925-1929, Ante-Nicene exegesis of the Gospels, SPCK, London.

Straub, J. (ed.), 1971, Concilium universale Constantinopolitanum sub iustiniano habitum, De Gruyter, Berlin.

Tholuck, A., 1860, Commentary on the Sermon on the Mount, Smith, English \& Co., Philadelphia.

Trapp, J., A commentary upon the Old and New Testaments, vol. 5, 2nd edn., Richard D. Dickinson, London.

Twomey, J., 2009, The pastoral epistles through the centuries, Blackwell, Malden.

Van de Sande Bakhuyzen, H., 1901, Der Dialog des Adamantius, JHinrich, Leipzig.

Wordsworth, C., 1864, The New Testament of our Lord and Saviour Jesus Christ, in the original Greek, vol. 1: The four Gospels, and Acts of the apostles, new edn., Rivingtons, London. 